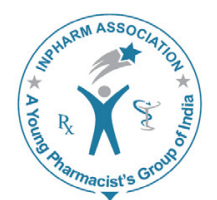

\title{
Anti-Inflammatory and Anti-Oxidant Study of Ethanolic Extract of Mimosa pudica
}

\author{
Shofiul Azam ${ }^{* 1}$, Archi Farhana Huda', Kishower Shams ${ }^{1}$, Prawej Ansari', \\ Mustafa Khalid Mohamed', Md Mahmudul Hasan', Abul Kalam Azad ${ }^{1}$ \\ Kallol Kanti Mondal ${ }^{3}$ and Shakil Mahmood Zaouad ${ }^{2}$ \\ ${ }^{*}$ Department of Pharmaceutical Sciences, North South University, Dhaka, Bangladesh \\ ${ }^{2}$ Department of Pharmacy, University of Asia Pacific, Dhaka, Bangladesh \\ ${ }^{3}$ Department of Pharmaceutical Science, Northern University, Dhaka, Bangladesh
}

\begin{abstract}
Objective: Our study includes the investigation of the phytochemical composition and in vitro free radical content and antiinflammatory activity of Mimosa pudica. Materials and Method: Free radical scavenging assay was done to evaluate the dose dependent reduction of free radical by ethanolic extract of Mimosa pudica, this activity was compared with a reference antioxidant i.e. Ascorbic acid. The anti-inflammatory potential of ethanolic extract of Mimosa pudica has been determined by using carrageenan-induced paw edema assay and Cotton wool granuloma in rats. Results: The $\mathrm{IC}_{50}$ of our sample was $24.55 \mu \mathrm{g} / \mathrm{ml}$, it's a very much promising result comparing to same reference. At the dose of $300 \mathrm{mg} / \mathrm{kg}$ the extract shows considerable inhibitory effect on paw increase 1 hour after carrageenan administration, by inhibiting nearly $50 \%$. The maximum inhibition ( $43.48 \%$; $p<0.001$ ) elicited by the ethanolic extract was recorded after 4 hours after carrageenan injection. Diclofenac sodium which is a reference drug showed a similar inhibitory effect 4 hours after carrageenan administration $(50.31 \%)$. The cotton wool granuloma is widely used to evaluate the transudative and proliferative components of chronic inflammation. Chronic inflammation occurs by means of the developments of proliferated cells and which can be spread in granuloma form. Non-steroidal anti-inflammatory drugs decrease the size of granuloma which results from cellular reaction by inhibiting granulocyte infiltration, preventing generation of collagen fibers and suppressing mucopolysaccharides. The extract showed significant $(p<0.01)$ anti-inflammatory activity in cotton wool induced granuloma with $33.64 \%$ of inhibition at higher dose. Conclusion: This finding suggests that ethanolic extract of $M$. pudica possess potent anti-inflammatory activity possibly due to its free radical scavenging properties.
\end{abstract}

Key words: Anti-oxidant, Carrageenan, Cotton oil, Inflammation, Mimosa pudica, Paw edema.

\begin{tabular}{|l|l|}
\hline \multicolumn{2}{|c|}{ Access this article online } \\
\hline \multicolumn{3}{|c|}{ Journal Sponsor } & $\begin{array}{l}\text { Website: } \\
\text { www.jyoungpharm.org }\end{array}$ \\
\cline { 2 - 2 } www.phcog net & $\begin{array}{l}\text { DOI: } \\
10.5530 / \text { jyp.2015.3.14 }\end{array}$ \\
\hline
\end{tabular}

\section{INTRODUCTION}

Plants have provided humans with many of their essential needs, including life-saving pharmaceutical agents. Recently the World Health Organization estimated that $80 \%$ people worldwide rely on herbal medicines for some aspect. There are more than 270,000 higher plants existing on this planet, but only a few has been explored scientifically for pharmacological use. So, it is anticipated that plants can

\footnotetext{
*Address for correspondence:

Mr. Shofiul Azam, Department of Pharmaceutical Sciences, 27/ka, Kuril, Dhaka-1229, Phone No : +8801815186262, Bangladesh.

E-mail : shofiul_azam@hotmail.com
} 


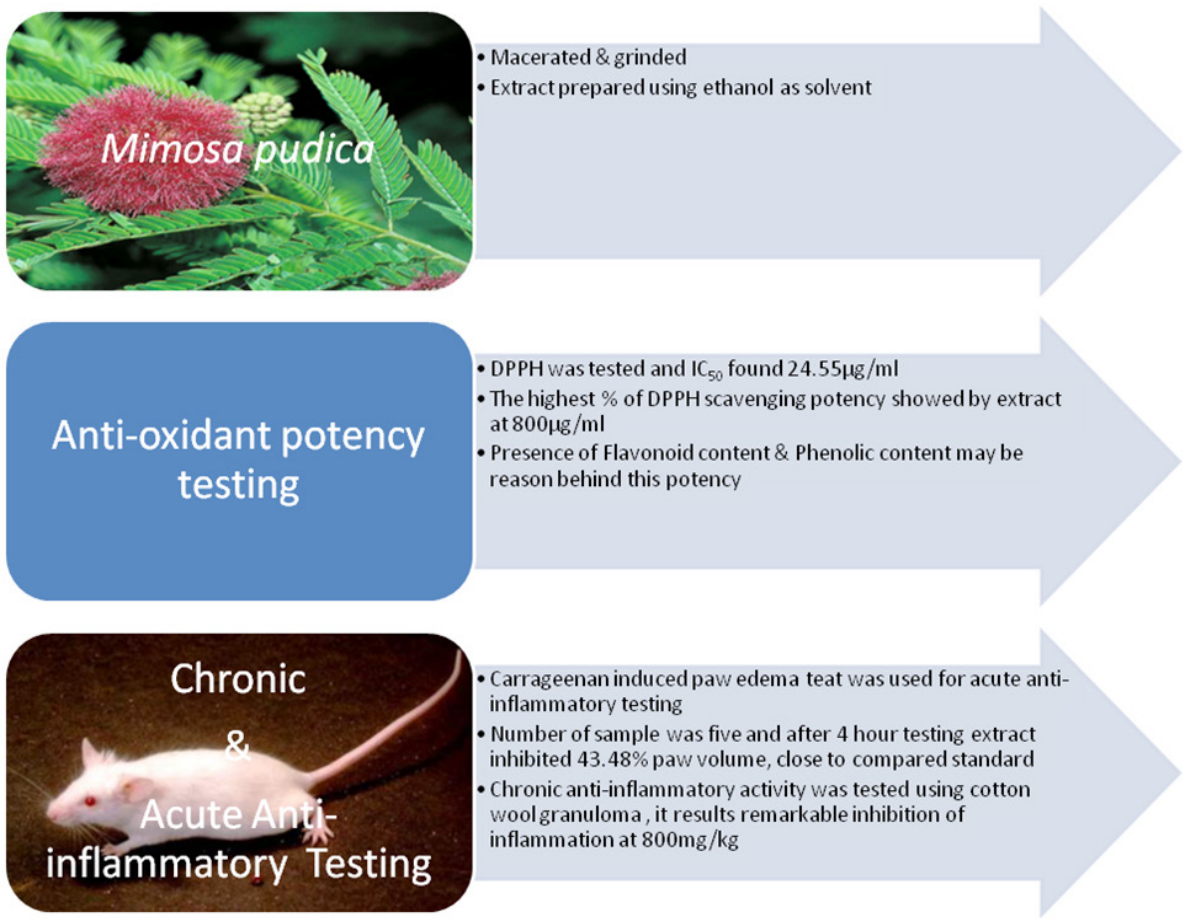

Graphical Abstract

provide potential bioactive compounds for the development of new 'leads' to combat various diseases. Mimosa pudica is most common herb in all locality of Bangladesh and its proved and important medicinal plant. Besides its local and traditional use it has many established pharmacologic use like, ovulation reduction ${ }^{1}$, anticonvulsant ${ }^{2}$, antidepressant ${ }^{3}$, anti-diabetic ${ }^{4}$, antimicrobial ${ }^{5}$, wound healing ${ }^{6}$, snake venom induced hyaluronidase and protease inhibition, snake venom neutralization, ${ }^{7}$ and antioxidant activities. ${ }^{8}$

The inflammatory response involves a complex array of enzyme activation, mediator release, fluid extravasations, cell migration, tissue breakdown and repair which are aimed at host defense and usually activated in most disease condition. ' Several phenomena alter the antigenicity of endogenous proteins, including protein denaturation and glycosylation. Protein denaturation may occur during chronic inflammatory phenomena in vivo and albumin denaturation was observed in patients with rheumatic diseases and in rats with inflammatory lesions. ${ }^{10}$ Lysosomal enzymes released during inflammation have been implied in acute or chronic inflammation. Many of the NSAIDs such as Diclofenac act by inhibiting these lysosomal enzymes or by stabilizing the lysosomal membrane. Since the membrane of RBC is structurally similar to lysosomal membrane, the effect of any substance on stabilization of RBC membrane may be extrapolated to the stabilization of lysosomal membrane ${ }^{11,12}$ It has been reported that leucocyte proteinases play an important role in the development of tissue damage during inflammatory reactions and significant level of protection was provided by proteinase inhibitors. Hence inhibition of albumin denaturation, RBC membrane stabilization and protease inhibition afford protection against chronic inflammatory conditions. ${ }^{13}$

Reactive Oxygen Species (ROS) play an important role in the pathogenesis of inflammatory diseases. Antioxidants capable of scavenging ROS are expected to improve these disorders. ${ }^{14}$ Hence we propose to study the anti-oxidant properties of the extracts for its ferric reducing anti-oxidant power and DPPH radical scavenging activity.

We propose to study anti-inflammatory activity and free radical scavenging capability of $M$. pudica by studying the traditional use on this purpose of this plant. M. pudica has been found to use in the treatment of edema, rheumatism, myalgia and in different painful condition in traditional and tribal medicine; however no scientific investigations yet been reported for its anti-inflammatory properties.

The phytochemical study reports (Table 1) following constituents of $M$ pudica: alkaloids, steroids, tannins, triterpenes, flavonoids, glycosides, quinines, phenols, saponin, coumarin, c-glycosylflavones. ${ }^{2,5}$ Presence of the flavonoids, phenols etc. encourages us more to study this plant, because these contents are responsible for wide range of anti-oxidant property, that means they aid protection against ROS and reduce damage of cell. 


\begin{tabular}{cc} 
Table 1: Preliminary Phytochemical Testing \\
Test of Constituent & Intensity of Presence \\
\hline Alkaloid & +++ \\
Flavinoid & +++ \\
Carbohydrate & +++ \\
Glucoside & +++ \\
Glycoside & +++ \\
Phenol & +++ \\
Saponin & +++ \\
Steroid & +++ \\
Tannin & +++
\end{tabular}

\section{MATERIALS AND METHODS}

\section{Collection and Extraction}

The plant was collected from Botanical Garden of Bangladesh, where this plant is harvested widely. It's an annual herb with tiny little cylindrical shaped leaf. We worked by using those leaves. Leaves were separated and dried at room temperature then extracted using cold extraction process; it is so called because no heat is applied in this process. Ethanol was used as solvent; we have got dark greenish black extract weighing $31.8 \mathrm{gm}$.

\section{Test for Anti-0xidant}

\section{Preparation of solutions}

Ascorbic acid was considered for comparative standard, which was concentrated $0.005 \mathrm{gm} / \mathrm{ml}$. Different concentrations for different tests were prepared by serial dilution from this solution, so far. $0.005 \mathrm{gm} / \mathrm{ml}$ of plant extract was prepared in ethanolic solvent for stock solution. From this solution, $800 \mu \mathrm{g} / 100 \mu \mathrm{l}, 400 \mu \mathrm{g} / 100 \mu \mathrm{l}, 200$ $\mu \mathrm{g} / 100 \mu \mathrm{l}, 100 \mu \mathrm{g} / 100 \mu \mathrm{l}$ and $50 \mu \mathrm{g} / 100 \mu \mathrm{l}$ was prepared for further use.

\section{Procedure}

In each concentration of plant extract solution, $3 \mathrm{ml}$ of DPPH solution was added and the mixture was incubated for 30 minutes in a dark place for proper reaction. Then the absorbance of the solution was measured at $517 \mathrm{~nm}$ using a spectrophotometer (Shimadzu, UV-1601 PC) against blank/control. ${ }^{14}$

\section{Anti-inflammatory testing}

\section{Animal selection}

Healthy male rats were selected weighing between 120-180 g. They were kept at room temperature with 12-h light and dark cycle.

\section{Carrageenan induced paw edema}

\section{Carrageenan}

Carrageenan (lambda form, FMC Marine Colloids Division, NJ, or type IV, Sigma Aldrich, Poole, UK) was prepared as a $1 \% \mathrm{~W} / \mathrm{V}$ solution in $0.9 \%$ saline, no more than 24 $\mathrm{h}$ before use. Carrageenan powder becomes extremely sticky on contact with water and may form lumps that are difficult to dissolve. Complete solution of solid material is vital to prevent blockage of the hypodermic needle bore and potential injury to the investigator by pressurized ejection of the needle from the syringe or breakage of the syringe barrel in the hand. The lambda form does not gel strongly at room temperature and is injectable to induce an inflammatory response. Inflammation induced by carrageenan, originally described. ${ }^{14}$

\section{Procedure}

Animals are weighed, randomized into groups $(n=5)$, and kept for 1 week to acclimatize to the laboratory conditions. Test compounds were administered to animals at an appropriate time point before carrageenan injection. Effects of unknown compounds are usually compared to reference compounds whose pharmacology and action in this model are known. Volume of pre-injection paw/ paws measured immediately prior to carrageenan injection, Plethysmometre were used to measure the swelling of paw. $100 \mu \mathrm{L}$ (rat) or $25 \mu \mathrm{L}$ (mouse) of a $1 \%$ solution of lambda carrageenan in $0.9 \%$ saline was injected subcutaneously into the plantar region of the left hind paw. Carrageenan injected and control paw volumes were measured hourly as required from $1-6 \mathrm{~h}$ and again at $24 \mathrm{~h}$.

\section{Cotton wool granuloma in rats}

This method is a chronic anti-inflammatory evaluation model. ${ }^{15}$

\section{Induction of Anesthesia}

The animals were sedated using proper dose of Ketamin, a general anesthetic used in minor surgery. The anesthetic was given intra-peritoneally and after 10 minutes as anesthesia established, the animal is ready for experiment.

\section{Procedure}

The furs of the axilla area were cleaned and were wiped with $70 \% \mathrm{v} / \mathrm{v}$ ethanol. A small subcutaneous incision was made in the axilla region and formed a pouch using blunt ended forceps. $20 \pm 1 \mathrm{mg}$ of the sterile cotton pellet was inserted into axilla. The incisions were sutured by sterile catgut/biodegradable surgical stings. 


\begin{tabular}{cccccc}
\multicolumn{5}{c}{ Table 2: Antioxidant Activity of the Ethanolic Extract of Mimosa pudica } \\
Sample & Conc. $(\mu \mathrm{g} / \mathrm{ml})$ & Absorbance & $\begin{array}{c}\text { Absorbance of } \\
\text { Control }\end{array}$ & $\begin{array}{c}\text { Mean } \% \text { DPPH } \\
\text { scavenging } \\
\text { activity } \pm \text { SD }\end{array}$ & $\begin{array}{c}\mathbf{C}_{50} \mathbf{V} \text { alue } \\
(\mu \mathrm{g} / \mathrm{ml})\end{array}$ \\
Standard & 50 & 0.080 & & $88.56 \pm 1.65$ & \\
Ascorbic Acid & 100 & 0.060 & & $91.56 \pm 0.95$ & \\
& 200 & 0.051 & & $93.15 \pm 0.79$ & $1.102 \mu \mathrm{g} / \mathrm{ml}$ \\
& 400 & 0.046 & & $94.07 \pm 0.26$ & \\
Ethanol Extract & 800 & 0.045 & 0.816 & $94.82 \pm 0 . .29$ & \\
Mimosa pudica & 50 & 0.288 & & $64.72 \pm 0.50$ & \\
& 100 & 0.214 & & $72.70 \pm 0.98$ & \\
& 200 & 0.193 & & $75.39 \pm 1.14$ & $24.55 \mu \mathrm{g} / \mathrm{ml}$ \\
& 400 & 0.179 & & $77.78 \pm 0.39$ & \\
& 800 & 0.134 & & $81.94 \pm 1.53$ &
\end{tabular}

All values are Mean $\pm S E M, n=3$. Independent Sample $t$-Test followed by Studentt-test was performed as the test of significance. P-value was $<0.05$ which considered statistically significant.

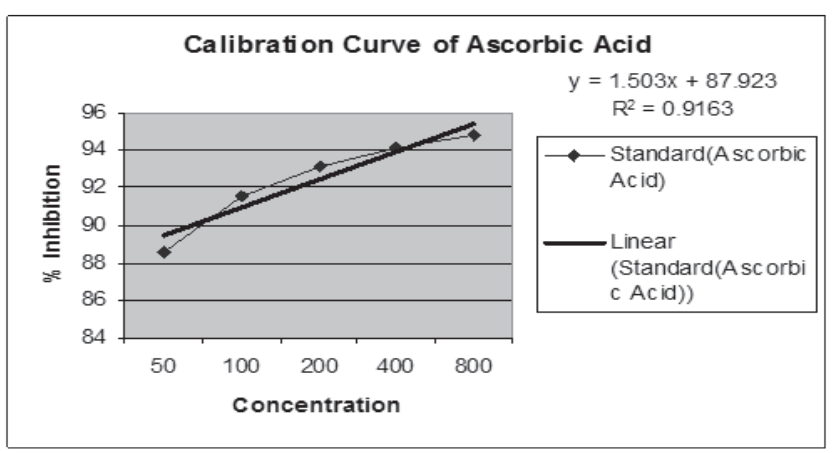

Figure 1: Calibration curve of ascorbic acid

\section{Removal of cotton}

The animals were sacrificed by excess anesthesia on the $8^{\text {th }}$ day and cotton pellets covered by the granulomaus tissue were removed surgically. Pellets were separated from extraneous tissue and dried at $60^{\circ} \mathrm{C}$ until weight become constant. Then the net weight was calculated following the equation:

$\%$ of inhibition $=\frac{w_{c}-w_{d}}{w_{c}} \times 100^{16,17}$

$\mathrm{W}_{\mathrm{c}}=$ Difference in the weight of control group

$\mathrm{W}_{\mathrm{d}}=$ Difference in the weight of extract group

\section{RESULT AND DISCUSSION of Free Radical Scavenging of Extarct of Mimosa pudica}

DPPH was used to evaluate the possible antioxidant principles present in the extract by its radical scavenging capacity measurement (Oyaizu, 1986). The \% of DPPH free radical Scavenging was determined by using the following equation.

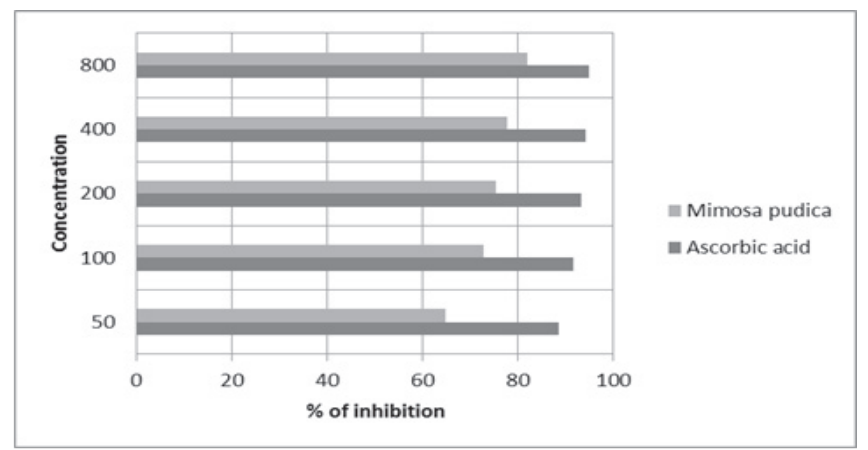

Figure 2: Percent of DPPH Scavenging Activity of Extracts and Ascorbic Acid

$\%$ of DPPH free radical Scavenging= [(Absorbance of controlAbsorbance of test sample)/ absorbance of control] $\times 100$

DPPH radical scavenging is a widely used method to evaluate the free radical scavenging ability of various materials. DPPH is a stable nitrogen-centered free radical, the color of which changes from violet to yellow upon reduction by either the process of hydrogen-or electrondonation. Substances which are able to perform its reaction can be considered as antioxidants and, therefore, radical scavengers. It was found that the radical scavenging activitie of the extract increased with increasing concentration. High total phenol content and total Antioxidant Capacity of the ethanol plant extract may be a reason for its higher DPPH-scavenging activity.

The results were calculated as $\mathrm{IC}_{50}$ values, which denotes the concentration of sample required to scavenge $50 \%$ of DPPH free radicals (Table 2).

In this assay, plant extract showed dose dependent scavenging of DPPH radicals (Figure 1 and 2) in a way similar to that of the reference antioxidant ascorbic acid. 


\begin{tabular}{|c|c|c|c|c|c|}
\hline \multirow{3}{*}{ Treatment Group } & \multicolumn{5}{|c|}{ Paw Volume } \\
\hline & & & Time & & \\
\hline & 0 hour & 1 hour & 2 hour & 3 hour & 4 hour \\
\hline Control & $0.73 \pm 0.111$ & $1.19 \pm 0.231$ & $1.39 \pm 0.071$ & $1.56 \pm 0.144$ & $1.61 \pm 0.164$ \\
\hline Standard & $0.76 \pm 0.085$ & $0.98 \pm 0.058$ & $1.16 \pm 0.098$ & $1.05 \pm 0.226$ & $0.8 \pm 0.094$ \\
\hline Drug $100 \mathrm{mg} / \mathrm{kg}$ & $0.78 \pm 0.094$ & $1.05 \pm 0.095$ & $1.35 \pm 0.156$ & $1.11 \pm 0.223$ & $1.07 \pm 0.222$ \\
\hline Drug 200 mg/kg & $0.71 \pm 0.069$ & $1.03 \pm 0.109$ & $1.29 \pm 0.215$ & $1.1 \pm 0.227$ & $0.97 \pm 0.121$ \\
\hline Drug 300 mg/kg & $0.75 \pm 0.093$ & $1.01 \pm 0.241$ & $1.26 \pm 0.149$ & $1.06 \pm 0.175$ & $0.91 \pm 0.265$ \\
\hline
\end{tabular}

Values are expressed as mean \pm standard error of the mean (SEM). Data were analyzed by analysis of variance (ANOVA)

followed by post hoc analysis with a one-tailed Dennett'st-test for multiple comparisons.

\section{RESULT AND DISCUSSION of Carrangeenan Induced Paw Edema}

\begin{tabular}{|c|c|c|c|c|}
\hline \multirow{3}{*}{$\begin{array}{l}\text { Treated } \\
\text { Groups }\end{array}$} & \multirow{2}{*}{\multicolumn{4}{|c|}{$\begin{array}{c}\% \text { Inhibition } \\
\text { Time }\end{array}$}} \\
\hline & & & & \\
\hline & 1 hour & 2 hour & 3 hour & 4 hour \\
\hline Standard & 17.65 & 16.55 & 32.69 & 50.31 \\
\hline Drug $100 \mathrm{mg} / \mathrm{kg}$ & 11.76 & 2.88 & 28.85 & 33.54 \\
\hline Drug $200 \mathrm{mg} / \mathrm{kg}$ & 13.45 & 7.19 & 29.49 & 39.75 \\
\hline Drug 300 mg/kg & 15.13 & 9.35 & 32.05 & 43.48 \\
\hline
\end{tabular}

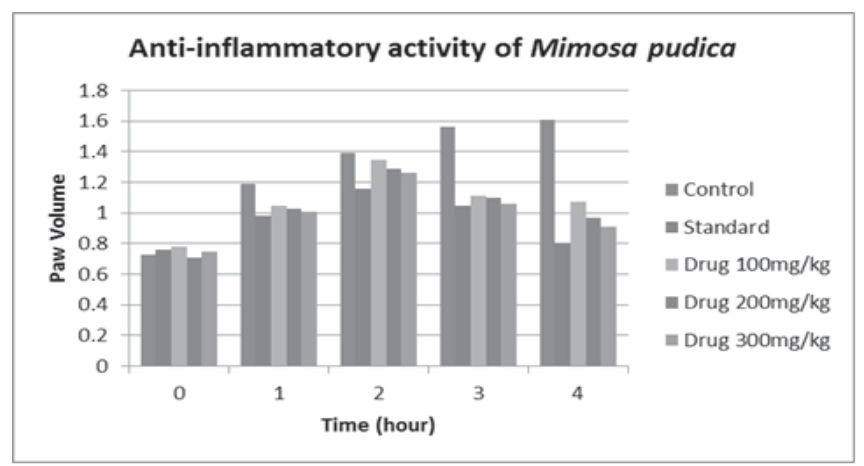

Figure 3: Anti-inflammatory Activity of Mimosa pudica
For each of the three doses of extract tested (100, 200 and $300 \mathrm{mg} / \mathrm{kg}$ ), the extract exerted considerable inhibitory effect on paw increase 1 hour after carrageenan administration, with near a 50\% inhibition for the dose 300 $\mathrm{mg} / \mathrm{kg}$ (Table 3 and 4). The maximum inhibition (43.48\%, $\mathrm{p}<0.001)$ elicited by the ethanolic extract was recorded after 4 hours after carrageenan injection. Diclofenac sodium which is a reference drug showed a similar inhibitory effect (Figure 3 and 4) 4 hours after carrageenan administration $(50.31 \%)$

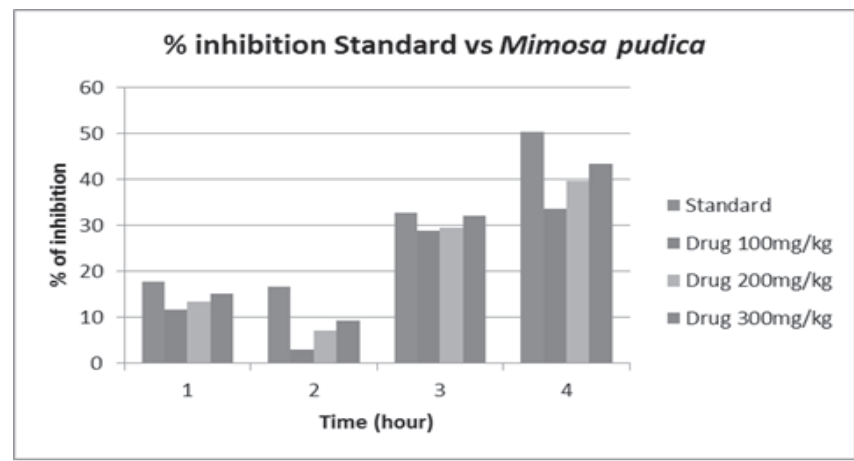

Figure 4:\% Inhibition of Mimosa pudica at carrageenan induced paw edema

\begin{tabular}{|c|c|c|c|c|}
\hline $\begin{array}{c}\text { Group and Dose of } \\
\text { Drug }\end{array}$ & $\begin{array}{l}\text { Weight of wet } \\
\text { Cotton Wool }\end{array}$ & $\%$ Inhibition & $\begin{array}{l}\text { Weight of Dry } \\
\text { Cotton Wool }\end{array}$ & $\%$ Inhibition \\
\hline Control (Water) & $299.17 \pm 5.69$ & - & $86.5 \pm 0.86$ & - \\
\hline $\begin{array}{c}\text { Standard } \\
\text { (Diclofenac Na } \\
10 \text { mg/ Kg) }\end{array}$ & $159.5 \pm 5.76^{*}$ & 46.69 & $44.33 \pm 1.4^{*}$ & 48.75 \\
\hline $\begin{array}{c}\text { Dose } 1 \text { (Extract } \\
200 \mathrm{mg} / \mathrm{Kg})\end{array}$ & $285.5 \pm 2.53^{\star}$ & 22.85 & $85.33 \pm 1.69^{\star}$ & 23.97 \\
\hline $\begin{array}{c}\text { Dose } 2 \text { (Extract } \\
400 \mathrm{mg} / \mathrm{Kg})\end{array}$ & $187.11 \pm 2.98^{*}$ & 29.12 & $55.33 \pm 1.26^{\star}$ & 31.88 \\
\hline $\begin{array}{c}\text { Dose } 3 \text { (Extract } \\
800 \mathrm{mg} / \mathrm{Kg})\end{array}$ & $180.5 \pm 2.85^{\star}$ & 31.22 & $53.33 \pm 1.2^{*}$ & 33.64 \\
\hline
\end{tabular}

Values are expressed as Mean $\pm S E M, n=4$ in each group. Data was analyzed by one way ANOVA followed by Dunnett's Test. ${ }^{*} \mathrm{P}<0.01$ as compared to control group, that means statistically significant. 


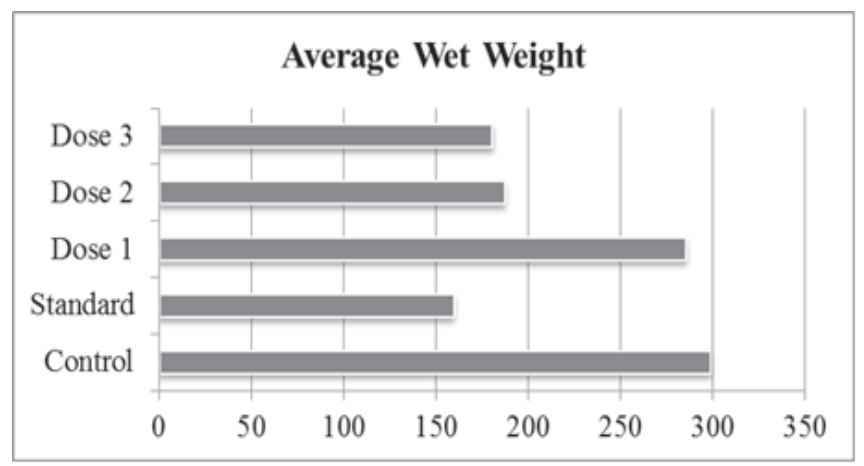

Figure 5: Effect of the Average Wet Weight of cotton Pellets with Respect to different groups

\section{RESULT AND DISCUSSION of Cotton wool granuloma test}

The cotton wool granuloma is widely used to evaluate the transudative and proliferative components of chronic inflammation. The moist weight of the wool correlates with transude, the dry weight of the wool correlates with the amount of granulumatous tissues. Chronic inflammation occurs by means of the developments of proliferated cells. These cells can be spread in granuloma form. Non-steroidal anti-inflammatory drugs decrease the size of granuloma which results from cellular reaction by inhibiting granulocyte infiltration, preventing generation of collagen fibers and suppressing mucopolysaccharides. The extract showed significant $(\mathrm{p}<0.01)$ anti-inflammatory activity in cotton wool induced granuloma (Table 5) and (Figure 5 and 6 ) and thus found to be effective in chronic inflammatory condition, which reflected its efficacy ininhibiting the increase in the number of fibroblasts and synthesis of collagen and mucopolysaccharides during granuloma tissue formation.

\section{RESULT of Phytochemical Testing}

\section{CONCLUSION}

In the present investigation we can conclude that the ethanolic extract of Mimosa pudica may have anti-oxidant and anti-inflammatory effect, which supports the traditional use of this plant in various diseases as traditional medicine.

The antioxidant activity of the root extract was tested by DPPH radical scavenging assay. In light of the result of the present study, it can be concluded that the plant extract possesses remarkable antioxidant potential. However, further studies are needed to understand the underlying mechanism of antioxidant action and to isolate the compound(s) responsible for such activity.

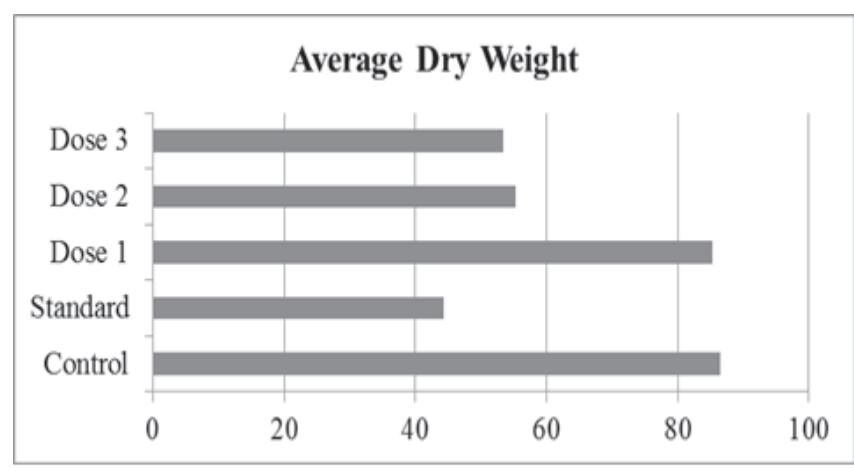

Figure 6: Effect of the Average Dry Weight of cotton Pellets with Respect to different groups

It is well known that carrageenan induced paw edema is characterized by biphasic event with involvement of different inflammatory mediators. In the first phase (during the first $2 \mathrm{~h}$ after carrageenan injection), chemical mediators such as histamine and serotonin play role, which in second phase ( $3 \mathrm{~h}$ after carrageenan injection) Kinins and prostaglandins are involved. Our results revealed that administration of Mimosa pudica extract inhibits inflammation which is caused by chemical or other mediators of inflammation.

The cotton wool granuloma is widely used to evaluate the transudative and proliferative components of chronic inflammation. The moist weight of the wool correlates with transude, the dry weight of the wool correlates with the amount of granulumatous tissues. Chronic inflammation occurs by means of the developments of proliferated cells. These cells can be spread in granuloma form. Non-steroidal anti-inflammatory drugs decrease the size of granuloma which results from cellular reaction by inhibiting granulocyte infiltration, preventing generation of collagen fibers and suppressing mucopolysaccharides. The extract of Mimosa pudica showed significant $(\mathrm{p}<0.01)$ antiinflammatory activity in cotton wool induced granuloma and thus found to be effective in chronic inflammatory condition, which reflected its efficacy in inhibiting the increase in the number of fibroblasts and synthesis of collagen and mucopolysaccharides during granuloma tissue formation.

\section{CONFLICTS OF INTEREST}

Authors declare no conflict of interest.

\section{ACKNOWLEDGEMENTS}

First of all we would like thank North South University 
for allowing us to use their lab, unless we will not eligible to finish our work. We also like to give special thanks to icddr'b (international center for diarrheal disease research, Bangladesh) for their help to manage our animal subject. Especial thanks to Mohammad Mamun Ur Rashid, graduate student, Department of Pharmaceutical Sciences, North South University, for his suggestion during article preparation.

\section{ETHICAL CONCERN}

Whenever we use any animal model it is our responsibility to take permission from appropriate authority for authentication. We took ethical consent from our university authority and also from icddr'b, when we were collecting animal and using in our study. So the whole study was run in an ethical manner.

\section{Highlights of Paper}

- Carrageenan increase cellular metabolism of Kinins and prostaglandins after $3 \mathrm{hr}$ of injection, as well as histamin release increased.

- All these mediators influence inflammation.

- Extract reduces inflammation after 4 hour because it either inhibits the prostaglandin synthesis or kinin.

- Cotton wool induction enhance the cell to proliferate.

- Mucopolysccharide and collagen fiber generates more, cell become inflammed.

- Extract prevents the inflammation by preventing generation of mucopolysccharide and collagen fiber, thus cell swelling prevented and chronic inflammation controled.

\section{Author Profile}

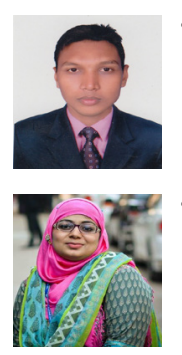

- Shofiul Azam, is an Graduate student of Department of Pharmaceutical Sciences, North South University. Completed honors (4 year Bachelor degree) from International Islamic University Chittagong. I am hanged up with different plants available in Bangladesh, evaluating their ethnopharmacological property, also trying to identify their phytochemical content. Recently working in a project with another plant and investigating its lipid lowering potency in hypertensive rat model.

Archi Frahana Huda, Completed her graduation program from North South University and also her 4 years bachelor program from same institute, under the department of Pharmaceutical Sciences. Now she is working in a renowned pharmaceutical farm in Bangladesh (Sk+F Pharmaceutical Ltd.) as a Product Management Officer. She was engaged in different pharmacological property investigation project during her graduate and under-graduate program. Antiinflammatory and anti-oxidant study of ethanolic extract of M. pudica, is also a part of her project.

\section{REFERENCES}

1. Valsala S, Karpagaganapathy PR. Effect of Mimosa pudica root powder on oestrous cycle and ovulation in cycling female albino rat Rattus norvegicus. Phytother Res. 2002; 16(2): 190-2.

2. Bum EN, Dawack DL, Schmutz M, Rakotonirina A, Rakotonirina SV, et al. Anticonvulsant activity of Mimosa pudica decoction. Fitoterapia 2004; 75(3): 309-14.

3. Molina M, Contreas CM, Tellez AP. Mimosa pudica may possess antidepressant action in the rat. Phytomedicine 1999; 6(5): 319-23.

4. Sutar NG, Sutar UN, Behera BC. Anti-diabetic Activity of the Leaves of Mimosa pudica Linn in albino rats. J Herbal Medicine and Toxicology 2009; 3(1): 123-6.

5. Gandiraja N, Sriram S, Meenaa V, Srilakshmi JK, Sasikumar C, Rajeswari R. Phytochemical Screening and Antimicrobial Activity of the Plant Extracts of Mimosa pudica L against selected Microbes. Ethnobotanical Leaflets 2009; 13(1): 618-24.

6. Kannan S, Jesuraj SAV, Jeeva KES, Saminathan K, Suthakaran $\mathrm{R}$, Ravi KM, et al. Wound healing activity of Mimosa pudica Linn formulation. Inter J Pharmtech Research 2009; 1(4):1554-8.

7. Girish KS, Mohanakumari HP, Nagaraju S, Vishwanath BS, Kemparaju K. Hyaluronidase and Protease activities from Indian snake venoms: neutralization by Mimosa pudica root extract. Fitoterapia 2004; 75(3): 378-80.

8. Genest S, Kerr C, Shah A, Rahman MM, Saif GMM, Nigam P, Nahar L, Sarker SD. Comparative bioactivity studies on two Mimosa species. Boletin Latinoamericano y del caribe de plantas Medicinales y Aromaticas 2008; 7(1): 38-43.

9. Rajendran V, Lakshmi KS. In vitro and in vivo anti-inflammatory activity of leaves of symplocos cochinchnesis (lour) Moore ssp laurina. J Pharmacol 2008; 3(1): 121-4.
10. Luciano S. Giovanni V, Maria LC, Eleonora M, Laura B, et al. Inhibition of Protein Denaturation by Fatty Acids, Bile salts and other Natural Substances: A New Hypothesis for the Mechanism of Action of Fish Oil in Rheumatic Diseases. Jpn J Pharmacol 1999; 79(1): 89-99.

11. Rajurkar R, Jain R, Matake N, Aswar P, Khadbadi SS. Antiinflammatory Action of Abutilon indicum $(\mathrm{L})$ Sweet Leaves by HRBC Membrane Stabilization. Res J Pharm Tech. 2009; 2(2): 415-6.

12. Chatterjee S, Das SN. Anti-arthritic and Anti-inflammatory Effect of a poly-herbal drug its mechanisam of action. Indian $\mathrm{J}$ Pharmacology 1996; 28(2): 166-19.

13. llavarassan R, Mallika M, Venkataraman S. Anti-inflammatory and Antioxidant Activities of Cassia Fistula Linn bark extracts. Afr J Trad CAM. 2005; 2(1): 70-85.

14. Parasuraman S, Petchi RR, Vijaya C, Dhanaraj SA. Evaluation of free radical scavenging properties and hypoglycemic activity of ethanolic extract of Tridax procumbens Linn. in Wistar rats. Drug Dev Ther. 2014; 5(1): 164-7.

15. Gerhard vogel H, Wolfganga HV, Bernward AS, Jurgen S, Gunter $\mathrm{M}$, Wolfganga FV. Drug discovery and evaluation pharmacological assays; 2nd ed; Berlin, Germany: Spinger; 2002; p-725-71.

16. Intahphuak S, Panthong A, Kanjanapothi D, Taesotikul T, Krachangchaeng C, Reutrakul V. Anti-inflammatory and analgesic activities of Mallotus spodocarpus Airy Shaw. J Ethnopharmacol. 2004; 90(1): 69-72.

17. Smita S, Shwetha K, Prabhu K, Maradi R, Bairy KL, Shanbhag T. Evaluation of antiinflammatory activity of Tephrosia purpurea in rats. Asian Pac J Trop Med. 2010; 3(3): 193-5. 